\title{
MAIN THEMATIC GROUPS OF TERMS USED IN POETRY OF 1960'S
}

Summary. The article is devoted to the research of the reproduction of terminological vocabulary as the constituent part of metaphorical expressions in the Anglophone translations of Ukrainian poetry of 1960's. A number of examples help to show that originally created metaphors are dynamic and expressive and that they evoke on the part of a reader a new range of individual associations. Preservation of these associations is considered in the study the most important criterion in judging the quality of translation.

Terms-metaphors have a role of key elements for understanding of national specificity of verbal vision of surrounding world. They are connected with nation's culture and they reflect results of cognitive activity of nation language group.

Before making the analysis of translation of the verses the role of terms (taken from different spheres of usage) and their functions in the untraditional for them style that is belles-lettres style and poetry in particular has been taken into account.

The research determines peculiarities of usage of terminological lexis as part of metaphorical expressions, it analyses stylistic devices used to achieve metaphorization. The focus is on the main thematic groups of terms. The analyses has shown that Ukrainian poetry of 1960's is enriched with physical, technical, chemistry, medical, geographical, artistic and musical terms; special words connected with space absorption (cosmic terms), achievements in the sphere of atomic physics and genetics.

As to personalities of the translators, the greatest bulk of the analysed poetry written by I. Drach was interpreted by Paul Nemser and Mark Rudman. If to speak about poems written by B. Oliynik, P. Perebiynis and O. Pidsukha, their translations were produced by Peter Tempest and Walter May. Two ways of translation prevailed in their verses: loan translation and descriptive paraphrase. Although all translators did not follow the idea to preserve structure of the poem, but all of them had one and the same aim - to preserve originally created metaphors, expressiveness which those metaphors had and to render the idea which each poem contained.

Certainly, the translators had lots of difficulties in finding solutions. Hopefully they have done their utmost attempts to provide the English readers with unprecedented samples of the Ukrainian literature.A significant positive development of the aforementioned translators is the rendering of Ukrainian poetry to the English-speaking readership.

Key words: essence of terms, terminological system, terminolexis, metaphor, metaphorization, metaphorical phrase.

Problem statement. Bright visual and audible imagination of the Ukrainian poets has always enriched the imagery content of their works. They heard the outer sounds in a unique way: they combined those things that can be heard and those that can be seen in a harmonious unity. To put it metaphorically, they saw a sound and heard a visual thing.

The usage of terms with the aim to give poetical texts emotionally-expressive colouring shows the intensification of terminolog- ical lexis role in a system of artistic-aesthetic devices of modern Ukrainian literary language. Terms which were eliminated from their natural sphere of functioning and later were used in the language of writers can be considered only as artistic-imagery device.

Broad usage of the analysed lexis in the language of Ukrainian poetry attests high communicative role of terminological units. The language of our poetry is enriched with physical, technical, chemistry, medical, geographical, artistic and musical terms; special words connected with space absorption (cosmic terms), achievements in the sphere of atomic physics and genetics.

Wide terminological usage is one of the prominent features of lexical processes which occur in the language of Ukrainian literature and poetical genre is not exceptional. As shown in the analysed work, terminology which functions in the works of prominent Ukrainian poets of the 1960 s of the $20^{\text {th }}$ century is diverse judging from its belonging to certain spheres of science and technology.

The purpose of the article is theoretical and methodological understanding of the reproduction of terminological lexis as an integral part of metaphorical constructions. The actualization of exploratory target anticipates determination of the main thematic groups of terms used in the Anglophone translations of Ukrainian poetry of 1960's.

The presentation of the main material and analysis of the research. I. Drach became one of those brave innovators (along with B. Oliynyk, M. Vinhranovskyi, L. Kostenko) who demonstrated a great potential of terminological lexis in the poetry. According to scholar L. Tykha, "even one successfully used term can give the poetic work deep-felt colouring of modern epoch" [11, p. 498].

I. Drach abundantly used physical, medical and musical terminolexis in his works. Prevailing of physical and chemical terminology in his poetry is not accidental. This fact can be explained by topicality of corresponding fields in the period when these poems were created:

\section{Навколо мідного ядра}

Живкі електрони, дві білки іржаві,

Гей, княжать на сосні [5, p. 19].

According to the Dictionary of the Ukrainian language, "ядро - фіз. важка, позитивно заряджена частина атома" $[9$, V. 11, p. 625]. The author as well made the use of another term from the physical sphere which is: "електрон - фіз. найлегша елементарна частинка речовини 3 найменшим негативним електричним зарядом" [9, V. 2, p. 471].

Чи ж фізики атомних псів розпустили?

Атомні сльози течуть в імлі

Не атомними сурмами безодні [5, р. 22].

Here the writer employed the terms ядро, електрон, атомний, атом which are normally used in physics. With the help of these lines the author skillfully demonstrates what unusual associations can stimulate the word атомний can stipulate when it acts 
as an epithet in the combination with commonly used words that have expressive colouring. The Dictionary of the Ukrainian language provides the following definition of the term: "атом - фiз. найдрібніша частинка хімічного елемента, що складається з ядра й електронів" [9, V. 1, p. 71].

In the following lines a combination of the term протон which defines particle of nuclear atom of any chemical element and manufacturing гудрон which in its turn defines substance used for oil refining develops into poetic symbol of the époque.

Згорає серпень золотим крилом,

Згорає серие всупір заборонам,

Відходимо - веслом і череслом,

Приходимо - протоном і гудроном [3, р. 41].

"Протон - хім. стабільна позитивно заряджена елементарна частинка атомного ядра будь-якого хімічного елемента" [9, V. 8, p. 324].

"Гудрон - чорна, густа, смолиста речовина, яку одержують після перегонки нафти; використовується як мастило в шляховому будівництві і т. ін.” [9, V. 2, p. 189].

The poetry by I. Drach is inimitable because it has no patterns and no stamps. The usage of different groups of terms, taken from various spheres of knowledge fields, helps the author to adhere to such position. However, it is necessary to mention that among terms used in poetical language there is a great number of words which differ in their restricted terminological meaning. They are not always understandable to wide readership. Introduction of terms with restricted meaning is a very effective method of intellectualization of poetic language. It is also a successful technique to involve the reader to the world of scientific achievements and searches. In such cases the knowledge of exact meaning of the term is scarcely ever important. In the poetry these terms function as signals of "non-artistic" style.

Irrepressible belief in social system brought about reinforced development of space theme in literature. By and large, space theme is characteristic of every transitional period. For example, poets of the 1920s analysed the space from microsystem to macrosystem, representatives of $1960 \mathrm{~s}$ - on the contrary, from macrosystem to microsystem. Great interest in cosmic terminology can be explained also by the well-known space race between the United States and the Soviet Union, including first human spaceflight with the Soviet Union's Vostok 1 mission in 1961. These remarkable events could partially influence the appearance of terminological units in the belles-lettres style, mainly in poetry.

As contemporary of 1960s, the époque of interest and activity in the space exploration, P. Perebyinis introduced cosmic theme in his poetry. Human entrance into space prompted romantic excitement in planetary scope and naïve belief in all-powerful science and technique:

Висить планета у зеніті року,

вишнево сяє червень за вікном [6, p. 82];

Що може поет в ивому світі -

Напитись сонетом води,

Погладити сонце в зеніті [4, р. 172];

Снігам на зустріч котиться планета,

Коротшають літа мої і дні [6, p. 82].

As we can see sometimes one and the same author is fascinated by certain terminological sphere. In the poetry by P. Perebyinis cosmic theme prevails, he produced us the following terms: "планета - небесне тіло кулястої форми, яке обертається навколо
Сонця і світиться відбитим сонячним світлом" [9, V. 6, р. 561]; "зеніт - найвища точка небесної сфери над головою спостерігача" [9, V. 3, р. 560].

Він підіймався вище й вище,

Минаючи дерев верхів'я,

Простуючи у свій зеніт [7, р. 36].

Musical terminology is also a very grateful material as it is easily connected with not only logical, but also emotional, expressive associations as in the following examples:

Вибухають сонати високо

В епіцентрі твоєї журби,

І симфонії чорні соколи

Гострять крила об чорні дуби [1, p. 164].

“Соната - інструментальний музичний твір, який складається 3 трьох-чотирьох різних щодо характеру та темпу частин, 3 яких одна має форму алегро" [10, p. 249].

I по клавішах сивого смутку

Ходять сині сумні слони [1, р. 165].

"Клавіш - пластинка в музичному інструменті (фортепіано, баяні тощо), ударяючи по якій, викликають звук” [10, p. 129].

In these cases terms preserve only some general indistinctly traced content lines, provoke approximate idea concerning the denoted concept. Along with I. Drach, L. Kostenko also shows preference to musical terms in her poetry. In many aspects the poetess is a novator in using neat metaphors, modern expressions, terms that claim attention and fall into the reader's heart:

Імісячну сонату уже створив Бетховен.

І тінь місяиехода вже зорям не чужа.

Десь грає ніч на скрипці самоти.

Десь виє вовк по нотах божевілля [8, p. 47].

"Скрипка - смичковий чотириструнний музичний інструмент, найвищий за регістром” [10, р. 248].

"Нота - умовний графічний знак, що позначав музичний звук цепної висоти і тривалості” [10, p. 198].

Натягне дощ свої осінні струни,

Торкне ті струни пальчиком верба [8, р. 51].

The personification of strings is frequently used in the creativity of L. Kostenko: А от нема. I струни його стихли... [8, p. 25]. The poetess extends the imagery associations connected with the word, which in her eyes symbolizes limitations, frames, burden of life:

А по ідеї: жінка ж-тільки жінка.

Смаглява золота віолончель $<\ldots>$

Хто ж натягнув такі скажені струни

на цю, таку струнку, віолончель,

що ій футляр - усі по черзі труни

вготованих для музики очей! [8, p. 39].

The word string ("струна - гнучка, пружна, туго натягнена нитка (металева, жильна і т. ін.) в музичних інструментах, що при коливанні створює звуки") [10, p. 259] forms a number of idioms which coincide with the meaning of the Ukrainian word cmpy$\mu a$ actualized in the analyzed poetry: no strings attached - "having no special conditions or limits on an agreement, relationship etc"; have somebody on a string - "be able to make someone do whatever you want" [12, p. 1646]. The last idiom has a related meaning to the lines from L. Kostenko's poetry. The author described uneasy woman's life: burdens which she has on her shoulders, problems she is faced with, rules that she must obey.

Here are some more samples which illustrate the use of musical terms by L. Kostenko: 
Від ніжного ноктюрна -

До громових симфоній [8, p. 42].

"Ноктюрн - одночастинний музичний твір наспівного, ліричного, мрійливого характеру” [66, р. 198].

Від буйного обурення -

До сміху саксофонів [8, р. 23].

The author compares the human laugh with the sounding of saxophone. This musical instrument produces a peculiar sound (“саксофон - мідний духовий музичний інструмент із характерним тембром") [10, p. 238] that is like an ironic laugh.

\section{Поезія згубила камертон.}

Хтось диригує ліктями й коліном.

Чи, може, ие ввижається мені

Той несказанний камертон природи [8, p. 21];

Зіграй мені мелодію любові,

Ту, без котрої холодно словам [8, p. 22].

Here the author used a simple metaphor "мелодія любові". The pure feeling of love is connected with pleasant music. Very often, music terms create an image of music that sounds from the very heart of a person who is in love. Those amorous feelings are transformed into poetic masterpieces. A great number of poetic expressions with the usage of musical terms can also be found in the descriptions of our fertile and blossoming motherland. Many authors associate different musical instruments, musical masterpieces and other musical terminology (е.g. "мелодія - художньо усвідомлена логічна послідовність музичних звуків, організованих ритмічно і ладово-інтонаційно") [10, p. 195] with natural phenomena. Very often poets like to draw an analogy between those musical terms and rain, storm, wind etc.

To sum up, the usage of musical terminology prevails mainly in those poems which describe bright feeling of love, description of natural phenomena, positive human feelings.

Another group of terms used in the poetry of "Shestydesiatnyky" represents the field of medicine. I. Drach, on the one hand, used such terms to describe miserable human's life, sufferings from enemies and persecution of people by Soviet regime. On the other hand, while using medical terminology the poet spoke about some goals, future tasks which are as vital to fulfill for a person, as blood is vital for human's body. Besides, such popularity of this terminology can be also explained by great achievements in medical sphere. Medicine made huge advances in the $20^{\text {th }}$ century: X-rays became powerful diagnostic tool for wide spectrum of diseases, from bone fractures to cancer; in the 1960s, computerized tomography was invented; the most difficult surgeries on the brain and the heart were made. Such important events could not but influence both average people and literature representatives, the so-called "creative minds". This can be seen from various lines of different poets:

Я- переклятий ворогом не тричі

(Рубцями ран закутана душа)

Дивлюся зорям в мерехтливі вічі... [5, p. 160];

Щоб капіляром променя до тебе

Прийти на землю і живити кров [2, р. 9];

Глухий - не чує, а сліпий - не бачить

Це тонізуюча ін'єкція майбутнього [2, р. 12];

... Ніч венозна

В артеріальну зореніс [3, p. 49].

The characteristic feature of L. Kostenko's idiostyle is an interpenetration of spatial images with metaphorical meaning. It under- lines emotional colouring, intensifies distinctness. The poetess is also fond of using medical terms in her poetry:

І я не я, і ти мені не ти.

Скриплять садів напнуті сухожилля [8, p. 43];

Кипить у нас в артеріях сучасність.

Нас із металу виклепав модерн [8, p. 20];

Спімать майстри... Допоки бачать очі

I не згасають пальці на різці,

\section{Допоки серце магмою клекоче -}

Cпімать любити сиві мудреці [6, p. 41].

P. Perebyinis in his poem "A master-craftsman's love" wanted to render to his reader the idea that the craftsman work until his heart is beating. And this process of heart beating is vital for any human being and we must understand that any person is a master at some field and we can do our best in that field until we are alive. We must fully devote ourselves to the work we do as long as we are able to do this.

Terms of art sphere belong to one of the most popular terminology fields used in the poetry of 1960s. Picturesque fields of our motherland inspired a lot of poets:

Нам треба неба без ліміту,

Землі нам треба й поготів.

Співмірна музика граніту

3 архітектурою хребтів [5, р. 200];

Призьба тече у вогненну шопу

3-під Вамого пензля з сипучого проса [5, p. 17];

І мліє палітра на згорблених спинах,

Розведена потом в мішках десятчаних [2, р. 14]; Зріють фарби земної палітри -

щчонайкращу із них вибирай! [6, р. 24].

These examples illustrate the popularity of usage of artistic terms. The lines given above belong to two different authors, but both poets used not only the terms of one sphere, they even based their images on the same term. P. Perebyinis in his work described the colourful palette of the nature. In the poem the author encouraged his reader not to grieve oneself over all difficulties sthe may face with during lifetime, but to enjoy one's life and be happy with time and place we live in.

Ivan Drach in his poetry associated artist's palette with hardworking person. Artist's palette of colours is assimilated with the palette of earth, the so-called painting of the hardworking people. So we can observe similar usage of terms by different authors. Such coincidences again stress on the one hand, the popularity of artistic terms usage among different poets. And on the other hand, the love and devotion of these people to their exclusive and unique motherland.

Conclusions. In conclusion, we may assert that out of all analysed poems a number of musical terms prevail over the terms taken from other spheres. The second place is occupied by medical terminology which was used by poets in those poems where there is a description of human sufferings under Soviet regime. The usage of medical terms in the analysed poems creates more expressive image of that period and in this way the reader can feel on his own a hard life of those people, can sympathize them.

There are as well a number of artistic terms used to render the love of each poet to his or her motherland. Metaphorical constructions created on the basis of terms are used to describe our picturesque views, beautiful weather, fertile fields, lovely people etc. 


\section{References:}

1. Драч І.Ф. Вибрані твори : в 2 т. / передм. Л. Новиченка. Київ : Дніпро, 1986. $351 \mathrm{c.}$

2. Драч I. Корінь і Крона. Поезії. Київ : Радянський письменник, 1974. $112 \mathrm{c}$.

3. Драч І.Ф. Лист до калини: Поезії / передм. Д. Павличка. Київ : Веселка, 1994. 286 с.

4. Драч І. Сонце і слово. Київ : Дніпро, 1978. 368 с.

5. Драч І. Неповторність: Вірші і поеми. Київ : Молодь, 1980. 224 с.

6. Перебийніс П. Червоний колір. Вибрані поезії. Київ : Дніпро, 1977. $247 \mathrm{c}$

7. Підсуха О.М. Вибрані твори : в 2 т. Київ : Дніпро, 1978. Т. 1: Пое3iï. $374 \mathrm{c}$.

8. Поезія: Ліна Костенко. Олександр Олесь. Василь Симоненко. Василь Стус. Київ : Наукова думка, 1999. 272 с.

9. Словник української мови : в 11 т. / ред.-упоряд. М. Мандрик. Київ : Наукова думка, 1970-1980. Т. 1-11.

10. Сучасний тлумачний словник української мови: 60000 слів / ред.-упоряд. В.В. Дубічинський. Харків : Видавн. дім «Школа», 2007. $832 \mathrm{c}$

11. Тиха Л. Термінологічна лексика як компонент метафоричних конструкцій (на матеріалі поезій Івана Драча). Вісник Львівського університету. Серія філологічна. 2004. Вип. 4. Ч. 1. С. 493-498.

12. Dictionary of Contemporary English. London : Pearson-Longman, 2005. $1928 \mathrm{p}$.

Кудринська Х. Основні тематичні групи термінів у поезії 1960-х pp.

Анотація. Стаття присвячена дослідженню відтворення термінологічної лексики - компонентів метафоричних конструкцій в англомовних перекладах української поезії 60-х pp. XX ст. Низка прикладів демонструє, що створені метафори є динамічними і виразними, формують у читача новий спектр окремих асоціацій. Збереження цих асоціацій розглядається як найважливіший критерій оцінки якості перекладу.
Терміни-метафори відіграють роль ключових елементів для розуміння національної специфіки словесного бачення навколишнього світу. Вони пов'язані з культурою нації та відображають результати пізнавальної діяльності іiї мовної групи.

Перш ніж почати аналіз перекладу віршів, ми зосередили увагу на ролі термінів (взятих із різних сфер використання) та їх функціях у нетрадиційному для них стилі, зокрема у стилі, характерному для написання художньої літератури та поезії.

Визначено особливості використання термінологічної лексики у складі метафоричних одиниць, проаналізовано стилістичні засоби, які уможливлюють процес метафоризації. Розглянуто функціональне використання термінів у художньому стилі та поезії. Значна увага фокусується на визначенні основних тематичних груп термінів. Аналіз показав, що українська поезія 60-х pp. XX ст. багата на спеціальну термінологію з таких сфер, як атомна фізика, хімія, медицина, географія, космос, мистецтво, музика тощо.

Що стосується особистостей перекладачів, то найбільшу частину аналізованої поезії, написаної Іваном Драчем, інтерпретували Пол Немсер і Марк Рудман. Якщо говорити про вірші, написані Борисом Олійником, Петром Перебійносом та Олександром Підсухою, то їх переклади здійснили Пітер Темпест та Уолтер Мей. У їхніх віршах переважали два способи перекладу: калькування (дослівний переклад) та описовий переклад. Згадані перекладачі не дотримувалися ідеї збереження структури поеми, однак усі вони мали одну мету - зберегти оригінальні метафори, виразність, яку ці метафори мали, передати ідею, котру містив кожен вірш. Суттєвим позитивом доробку вищезазначених перекладачів $\epsilon$ донесення української поезії до англомовної читацької аудиторії.

Ключові слова: сутність термінів, терміносистема, технічна термінологія, метафора, метафоризація, метафоричний вислів. 